\title{
ASSESSING INTERNATIONAL COMPETITIVENESS OF RENEWABLE ENERGY INDUSTRY IN KOREA AND ANALYZING ITS DETERMINANTS
}

\section{Yoon,Youngmin}

Attached Faculty of Economics, Lomonosov Moscow State University, Moscow, Russia / Participating Researcher in Asia-Pacific Research center, Hanyang University, Seoul, Republic of Korea

e-mail: yoonym81@gmail.com

Abstract. This article tries to assess the international competitiveness of Korean RES related products in the global market and its determinants. Many industrialized countries tires to take advantage in the newly growing market along with their national energy plans to develop renewables. The Republic of Korea is one of the representative countries seeking the advantage. Therefore, assessing the international competitiveness of Korea in the RES related products market and analyzing determinants affecting the competitiveness has significances in both ways of understanding features of the Korean energy industry and features of the global RES related products market. $R C A$ (Revealed Comparative Advantage) index is employed for assessing the international export competitiveness of Korea in the global RES related products market and determinants affecting the index are estimated by using DOLS (Dynamic Ordinary Least Squares).RES related products of Korea have competitiveness in the global market. In particular, solar energy products have the higher competitiveness than other sources and it has shown a rapid growth rate for the last decade. To improve competitiveness it is effective for Korea to take economic policies that help technological advancement and improvement of productivity such as investments and education than energy policy for increasing production of renewable energy.

Keywords: renewable energy products, international competitiveness, RCA index, cointegration regression, RES related industry in Korea.

Cite as: Yoon, Youngmin (2020) [Assessing international competitiveness of renewable energy industry in Korea and analyzing its determinants]. Intellekt. Innovatsii. Investitsii [Intellect. Innovations. Investments]. Vol. 3, pp. 42-52. DOI: 10.25198/2077-7175-2020-3-42.

\section{ОЦЕНКА МЕЖДУНАРОДНОЙ КОНКУРЕНТОСПОСОБНОСТИ ОТРАСЛИ ВОЗОБНОВЛЯЕМОЙ ЭНЕРГЕТИКИ В КОРЕЕ И АНАЛИЗ ЕЕ ДЕТЕРМИНАНТ}

\section{Ён Юнг Мин}

Московский государственный университет имени М.В. Ломоносова, Москва, Россия / АзиатскоТихоокеанский исследовательский центр, Ханьянский университет, Сеул, Республика Корея e-mail: yoonym81@gmail.com

\footnotetext{
Аннотация. Данная статья пытается оценить международную конкурентоспособность корейской продукции ВИЭ на мировом рынке и ее детерминанты. Многие промышленно развитые страны стремятся воспользоваться преимуществами нового растущего рынка наряду с их национальными энергетическими планами по развитию возобновляемых источников энергии. Республика Корея является одной из репрезентативных стран, стремящихся получить преимущество. Таким образом, оценка международной конкурентоспособности Кореи на рынке связанных с ВИЭ продуктов и анализ детерминант, влияющих на конкурентоспособность, имеет значение как для понимания особенностей корейской энергетической отрасли, так и для понимания особенностей глобального рынка, связанных с ВИЭ продуктов. Индекс RCA используется для оценки международной экспортной конкурентоспособности Кореи, а детерминанть, влияющие на индекс, оцениваются с помощью DOLS. Корейские продукты, связанные с ВИЭ обладают конкурентоспособностью на мировом рынке. В частности, продукция солнечной энергетики имеет более высокую конкурентоспособность, чем другие источники, и за последнее десятилетие она показала высокие темпы роста. Для повышения конкурентоспособности Кореи эффективнее проводить экономическую политику, способствующую технологическому прогрессу и повышению производительности, такую как инвестиции и образование, чем энергетическую политику по увеличению производства возобновляемых источников энергии.
}

Ключевые слова: продукты, связанны с возобновляемыми источниками энергии, международная конкурентоспособность, индекс RCA, регрессия коинтеграции, Корейская промышиленность, связанная с ВИЭ. 
Для цитирования: Yoon, Youngmin (2020) [Assessing international competitiveness of renewable energy industry in Korea and analyzing its determinants]. Intellekt. Innovatsii. Investitsii [Intellect. Innovations. Investments]. Vol. 3, pp. 42-52. DOI: 10.25198/2077-7175-2020-3-42.

\section{Introduction}

Renewable energy sources (RES) are de ned as energy sources that are continually replenished by nature and derived directly from the sun (such as thermal, photochemical, and photo-electric), indirectly from the sun (such as wind, hydropower, and photosynthetic energy stored in biomass), or from other natural movements and mechanisms of the environment (such as geothermal and tidal energy)[1]. They are considered to be one of the most important factors for the transition to sustainable development not only at the global level but also at the level of the individual country. In comparison with fossil fuel resources, RES has a more industrial character in their production process, because different and new infrastructures, equipment and technologies for the production of electricity and heat from RES are required. Also, in terms of industry and trade, the commodities associated with RES isan emerging market. This is why many countries, especially developed countries, are seeking to increase the share of renewable energies in its energy mix and give priority to the development of the RES industry in the transition of the energy mixfrom fossil fuels to renewable energy sources in their energy strategy. In other words, the development of RES has importance not only for the country's energy sector from the point of view of sustainable development but also for the country's trade sector in terms of economic growth. In this context, the Republic of Korea is a typical subject of the country, which is trying to develop the renewable energy industry because of its conditions of the energy sector and economic structure. The import dependency of energy resources in Korea has marked over $90 \%$ because it has no endowed energy resources in its territory. And the economy of Korea heavily depends on trade. According to World Bank statistics, Korea's dependency on trade (\% of trade to GDP) is more than $80 \%$ in 2017 and trade in goods takes $68 \%$ of GDP. So, in Korea, the development of RES and its competitiveness is important as energy policy and economic growth. This article assesses the international competitiveness of the Korean renewable energy industry in the international market using the RCA index and analyzes its determinants using cointegration analysis.

\section{Literature review}

Conceptually, both the researches on determinants of renewable energy development and factors influencing the competitiveness of renewable energy products need to reviewed as existing researches on the subject. Researches on the determinants of Chinese renewable energy development and its competitiveness.
Zhao \& Chen [2] conduct an analysis of the development factor of renewables in the Chinese power generation sector. By identifying diverse critical factors and methods, the authors extract 33 critical factors influencing energy sectors, economy, and policy. As the result, the article reveals the most critical factors, which are power network access capability and longdistance transmission capability, power consumption, independent $\mathrm{R} \& \mathrm{D}$ and innovation ability, alleviate the emissions of $\mathrm{CO} 2$, waste gas, wastewater, and solid waste, and local consumption of power generated by renewables. Boqiang Lin et al. [3] analyze factors affecting the share of renewable electricity in total electricity consumption in China by using the VECM (Vector Error Correction Model) based on data from 1980 to 2011. The authors conclude that GDP per capita, trade openness, foreign direct investment, financial development and share of fossil fuel in energy consumption have long-run relationships with renewable electricity consumption. Shuai et al. [4] assessthe international competitiveness of Chinese products related to biomass energy by using CMS (Constant Market Share) model and RCA index. The authors conclude that although the competitiveness of Chinese biomass energy products is increasing, it doesn't have a comparative advantage in the global market. The article assesses the competitiveness of biomass energy products and analyzes its position in the market, but it doesn't identify determinant factors for improving competitiveness.

Studies on the multinational analysis focus on not only diverse economic factors but also policy factors. Monika et al.[5] try to identify determinants of renewable energy development in the European countries. In order to reveal the determinants, the authors analyze the changes in the distribution of RES in $26 \mathrm{EU}$ countries in the period between 1995 and 2014. The article considers the distribution as a crucial factor in uencing energy policy in each country as well as energy security, environmental concerns, economic factors. Using the best subset regression and LARS method, the article shows that the current share of RES in the energy mix signi cantly depends on the condition of the EU countries in the middle of 1990s. in addition to this, it turns out that GDP per capita, concentration of energy supply (SWI), and the costs of consumption of energy obtained from fossil fuels in relation to GDP are also important factors affecting development of renewables. Onno et al. [6] examines the in uence of domestic renewable energy policy on the export of renewable energy products using a gravity model based on the data from over 40 countries. In order to assess the impact of the policy the authors employ the installed capacity of renewable as the 
proxy variable and show that renewable energy policies give a positive impact on the export performance of renewable energy products. A. Marques et al.[7] analyze the impact of factors on the use of renewable energy sources in a set of EU countries, by applying a quantile regression approach. The article considers diverse factors affecting the share of renewables of TPES, such as $\mathrm{CO} 2$ per capita, energy consumption per capita, importance of fossil fuel resources to electricity generation, import dependency of energy, GDP, price of fossil fuel resources, and the surface area. The results reveal that environmental concerns have not yet achieved enough pressure to stimulate major developments on renewables. Wojciech and Justyna[8] try to examine determinants of renewable energy production in transition countries using extensive data from 27 transition countries from 1990 to 2014. The authors reveal that GDP growth rate, unemployment level, and level of government debt have a signi cant impact on the renewable energy generation. Yoo[9] analyzes the international competitiveness of the renewable energy industry and its determinants using data from 42 countries. In the article, both RCA and TSI are used for assessing the competitiveness and employs method System GMM. In the model the author considers number of patent and GDP as the independent variables and employs FIT (Feed-In Tariff) and RPS (Renewable Portfolio Standard) as the dummy variables. Kim[10] focuses on the effects of the regulations and the government's effectiveness on the development of renewables. The author conducts panel data analysis using data from 71 countries. As a result, the share of applying regulation policy and effectiveness of government gives a positive effect on the share of renewables in total electricity generation. Meanwhile, the high effectiveness of the government strengthens the positive effect of the regulations, the low effectiveness compensates for the positive effects. Kim[11]conducts panel analysis effects of representative policies in the renewable energy sector, FIT and RPS, on the development of renewable energy sources in power generation. The author concludes that FIT and RPS don't have signi cant effect on the development of renewables. Otherwise, factors on energy policy governance, the national income level, business environment, and the level of international pressure have signi cant impacts on the development. Kai et al.[12] tries to assess the competitiveness G20 countries in the renewable energy sector by using modied Porter's Diamond Model. The authors identify 10 factors of assessments of development level in renewable energy sector, such as resource abundant, capital input into the sector, technological level, numbers of the employed person in the renewable energy industry, market scale, retail price of gasoline, GHG emission per capita, policy factors, and so on. The article doesn't provide any clues on what is the critical factors and how much impact they have.

\section{The export of RES related products of Korea}

The trade data for calculating the RCA(Revealed Comparative Advantage) index was obtained from UN Comtrade, and the maximum length of data was used. The problem is to classify the renewable energy industry. The de nition of the renewable energy industry and the technical classi cation of the sub-industries are relatively systematic, but the classi cation of HS codes is not clear yet, so it is often different by researchers and research institutes. We used the classi cation criteria of Jha (2009)[13], in which the classi cation of sub-industries is clear. The detailed HS code for each renewable energy source is shown in (table 1).

Table 1. HS Code by type of RES, 6-digit

\begin{tabular}{c|l}
\hline Type of RES & \multicolumn{1}{c}{ HS Code } \\
\hline \multirow{2}{*}{ Biomass } & $\begin{array}{l}730900,761100,840681,840682,841620,841931,841940,841989,842129,842139,847920, \\
847989,220710,220720,380210,382490,741999,841182\end{array}$ \\
\hline \multirow{2}{*}{ Hydro } & $\begin{array}{l}841011,841012,841013,850161,850162,850163,850164,850421,850422,850423,850431, \\
850432,850433,850434,382450,681091,841090\end{array}$ \\
\hline Geothermal & $841861,841950,730431,730441,730451,741121,741122,741129$ \\
\hline \multirow{2}{*}{ Solar } & $711590,732290,830630,841280,841919,850239,850440,900580,901380,700991,700992$, \\
Wind & $830890,761090,900190,900290,841990,854140$ \\
\hline Ocean & $840231,890790,902830,903020,903031,903039,903289,730820,841290,848210,848220$, \\
\hline
\end{tabular}

Source: Jha (2009)[13]

According to UN Comtrade, the total volume of international trade in products related to renewables has grown for the last decades. In 1988 the total value of exported products related to renewables was 23.5 bil- lion dollars. In 2000, it became almost 8 times of 1988, 183 billion USD, and has reached to 664 billion USD in 2014. The driving sources were the solar, wind and bioenergy industry. Especially, total exported products 
related to the solar power sector have shown a remarkable increase since 2000 as seen in [figure 1]. It was about a billion USD in 1988 and rapidly increased since 2002. In 2016, it records 228 billion USD and
$39 \%$ of total exported products related to renewables. The products related to wind and bioenergy follow with $27 \%$ and $22 \%$ of market share.

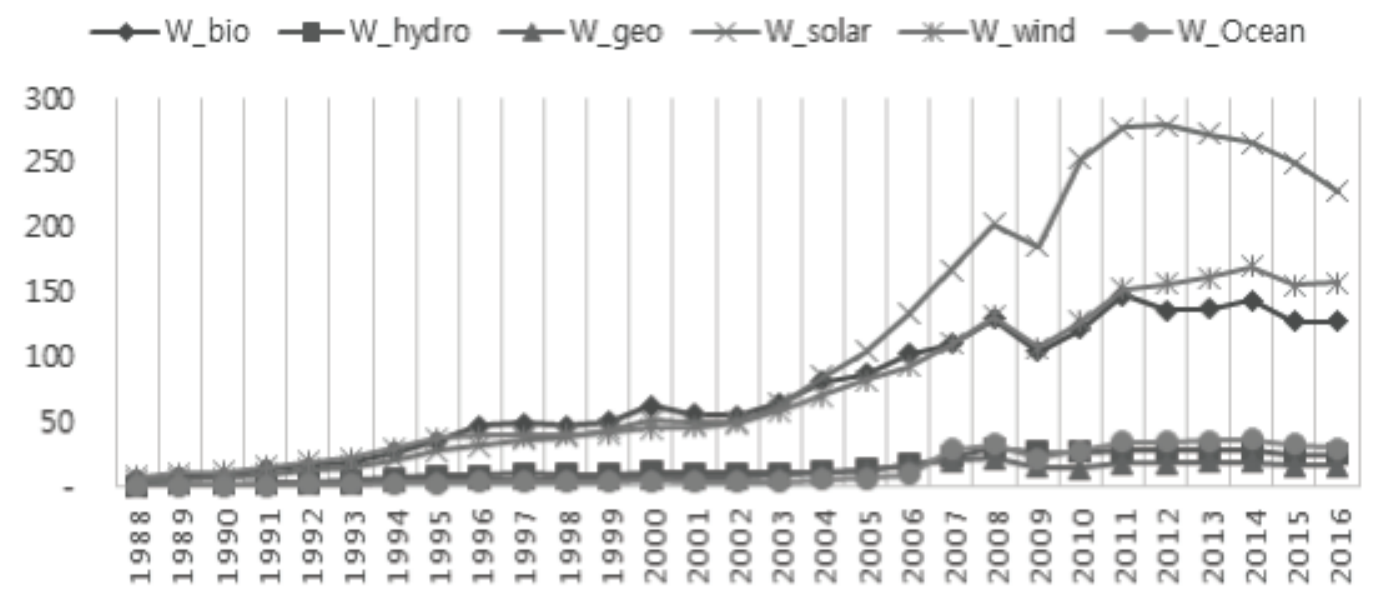

Figure 1. World total export value by RES sources

Source: UN Comtrade data ${ }^{1}$

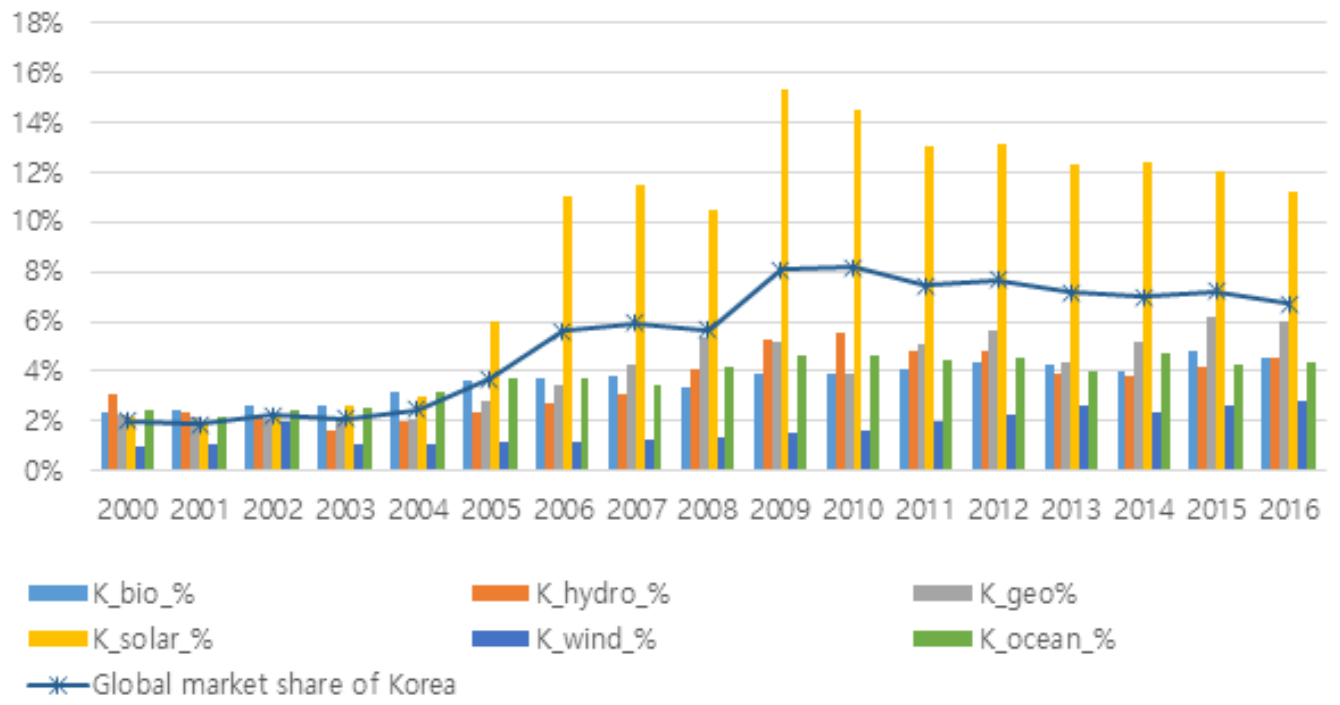

Figure 2. The share of Korea in the global market of RES related products Source: UN Comtrade data ${ }^{2}$

In 2016, Korea exports 39 billion USD, which is about $6.7 \%$ of the total exported products related to renewables. As shown in [figure 2], the share of Korea in the world total has grown since 2000 but looks a stagnant trend in the 2010s. The leading source in Korea's export of products related to renewables is solar power. Since 2005 Korea has expanded its share in total export related to solar power and it takes $11 \%$ in 2016 . On the other hand,

\section{Assessing the international competitiveness of the renewable energy industry in Korea}

International competitiveness can be de ned as the ability of a country to achieve economic policy ob-

UN Comtrade. UN Comtrade Database. Available at: https://comtrade.un.org/(accessed 16.12.2019) (in English).

UN Comtrade. UN Comtrade Database. Available at: https://comtrade.un.org/(accessed 16.12.2019) (in English). 
jectives such as income growth and full employment under the balance of external sectors (Fagerberg, 1988 [14]; Boltho, 1996 [15]). It is not limited to a single country but is a relative concept that can be applied to individual economic entities such as industry or corporation. It is also used as an indicator of a country's trade performance in international trade. In other words, the international competitiveness of individual commodities or certain commodity groups in international trade may be understood as export competitiveness in the sense that the speci c commodity of the speci $c$ country can be relatively preferred than the speci $c$ commodity of the other country in the international commodity market. The export competitiveness of individual products is used differently by researchers depending on the purpose of analysis and availability of data. The most commonly used indicator for export competitiveness is the global market share or growth rate (Magnier and Toujas-Bernate (1984) [16], Carlin et al. (2001) [17], Fargerberg (1988) [14], Amable and Verspagen (1995) [18]). Greenhalgh et al. (1994) [19] used the export/import ratio as an index of export competitiveness. Hulst et al. (1991)[20] used the RCA as an indicator of export competitiveness. We will use the RCA index, one of the most commonly used indicators in export competitiveness analysis research, to assess the international competitiveness of the renewable energy industry in Korea. The RCA index is a measure of how much the export in a particular industry is greater than the share of exports in the whole industry. If this value is greater than 1 , it can be interpreted that the industry has a comparative advantage. The calculation formula is as follows.

$$
R C A=\frac{x_{i j} / \Sigma_{i} x_{i j}}{\sum_{j} x_{i j} / \sum_{i} \Sigma_{j} x_{i j}}
$$

Where,

$X_{i,:}$ : export of product $j$ of country $i$ (in USD);

$\sum_{i} X_{i j}$ : total global export of product $j$ (in USD);

$\Sigma_{i}^{i} X_{i j}^{i j}$ : total export of country $i$ (in USD);

$\Sigma_{i} \Sigma_{i} X_{i j}$ : global total export (in USD).

The composite RCA index is the sum of RCA indices for each renewable energy source weighted by the share in the global market by sources.

$$
R C A_{\text {all }}=\Sigma_{i} w_{i} R C A_{i}
$$

$R C A_{i}: R C A$ index of renewable energy source $i$

$w_{i}$ : share of renewable energy source $i$ in global market

The RCA index by sources and composite RCA index for the renewable energy industry in Korea calculated using the above method are shown in [Figure 1]. Korea's comprehensive RCA index has grown rapidly in the mid-2000s. It was below 1.0 by 2004, increased to 2.72 in 2009 and recorded 2.10 in 2016. This rapid

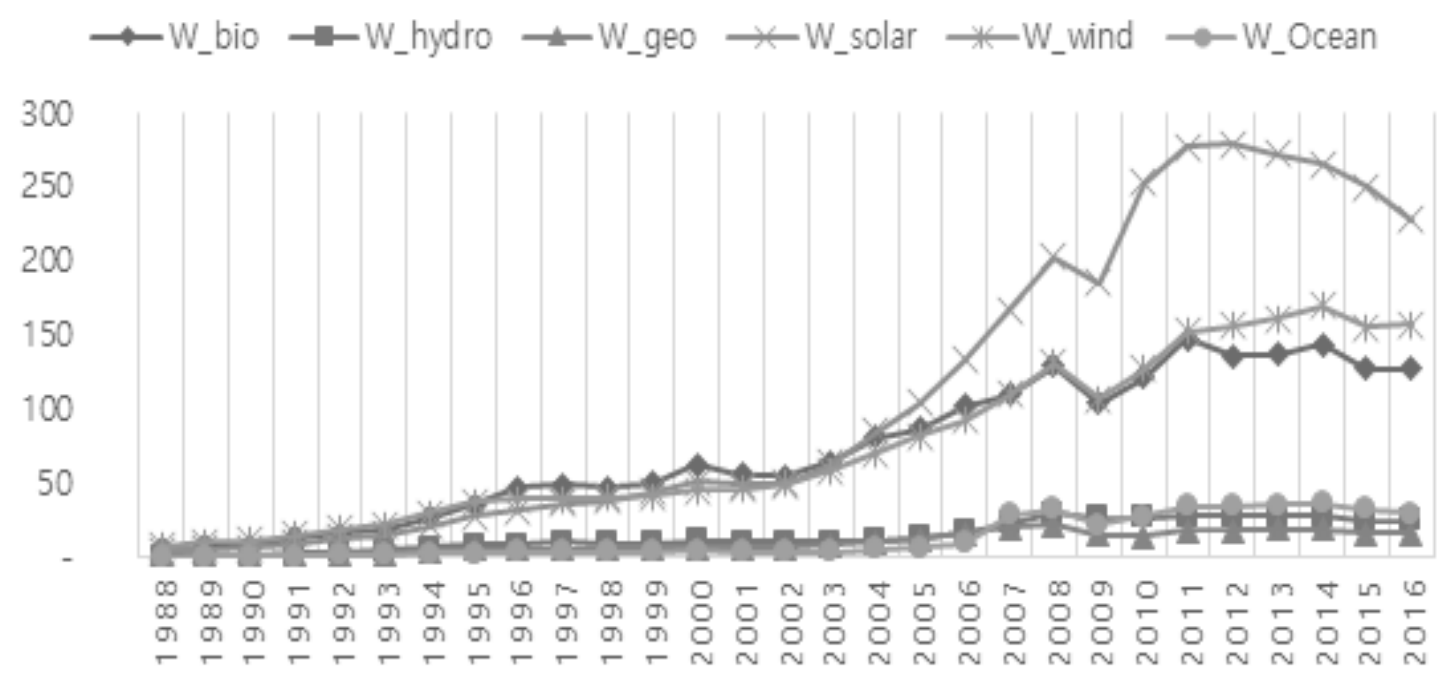

Figure 3. RCA index of the renewable energy industry in Korea, Japan, China, and Russia Source: Calculated by the author based on Comtrade data 
increase in the index is due to a sharp increase in the RCA index for solar energy. By drastic increase from 0.87 in 2002 to 3.53 in 2016 solar power products of Korea has higher relative competitiveness and it has stimulated the improvement of the composite RCA index of Korea. Such development in solar power products could be attributed to the huge increase in the export of "optical devices, appliances, and instruments (HS-code: 901380)". The export value of the category has been less than a billion USD by 2003(except for 1998 and 1999). Since 2004, the export value has increased drastically by 29.6 billion USD in 2011 and then it has decreased by 15 billion USD in 2016 . In 2010s, the "Photosensitive/photovoltaic/LED semiconductor devices (HS-code: 854140)" and "Structures and parts of structures, iron or steel (HS-code: 730890)" also show grown features, from 1.3 billion USD in 2009 to 4.1 billion USD in 2016 and from 0.8 billion in 2010 USD to 3.4 billion USD in 2016 . However, it is not so impressive compared to "optical devices, appliances, and instruments (HS-code: 901380)". As we've seen in [Figure 1] the solar power products are the most rapidly growing market among the RES related products. The share of solar energy in the global renewable energy industry increased from $28 \%$ to $38 \%$ in the same period, contributing to the increase of the comprehensive RCA index of Korea's renewable energy industry.

\section{Empirical analysis}

Now, let us estimate the determinants of the comprehensive RCA index of Korea, calculated as above. In this study, we use DOLS (Dynamic Ordinary Least Squares), which is a common time-series estimation method using cointegration as the main coef cient estimation method. The cointegration refers to a longterm equilibrium relation among non-stationary I (1) variables, which have the unit root and DOLS is one of the representative estimation methods for the cointegrated non-stationary I (1) variables. Since the cointegration regression could be de ned among non-stationary I (1) variables, it is necessary to check whether the variables are non-stationary I (1) using the ADF unit root test and to verify the existence of cointegrated relations among them using Johansen cointegration test. When the variables pass the tests, we can estimate the coef cients of the independent variables affecting RCA with the help of method DOLS. The ADF unit root test, Johansen cointegration test, and DOLS are all well know and widely used methods, so here we skip the detailed explanation on them. For detail, see Engle, R. F., \& Granger [21], Johansen, S [22], and Bae [23].

Jha (2009) have indicated that the development of R\&D or technology level has a direct or indirect effect on exports ofproducts related to renewable energy. This is quite persuasive. The renewable energy industry is a newly developing area in the energy sector and in- dustry. Renewable energy sources that are leading the sector such as solar, wind, tidal energy have tech-intensive features than the traditional fossil energy industry. Therefore, the development of the technology level is expected to have a positive impact on the composite RCA index of the renewable energy industry. We use the total number of patents as proxy variables for the technology level.

As another factor influencing the international competitiveness of a particular industry, we can consider the size of the domestic market. It is expected that the increase in economies of scale and scope by the development of the domestic renewable energy market can improve the international competitiveness of the renewable energy industry. We use renewable energy output per capita as its proxy variable. The other factor we can consider is productivity. In general, the export competitiveness of certain manufacturing products in individual countries is known to be affected by productivity.

Products of the renewable energy industry are basically manufacturing products like other commodities in the global market. Therefore, they have to compete with each other in quality and price and productivity directly affects price factors. Here, as the proxy variable, we use unit labor costs, which is widely used for assessing the productivity of a country.

The last factor to be considered is the industrial basement. Renewable energy-related products are basically industrial products. Therefore, it can be considered that the development level of the industry will directly or indirectly affect the export of renewable energy-related products and international competitiveness. We use the share of the industrial sector in GDP as a proxy for the level of industrial development. The total number of patents and the share of the industrial sector in GDP are taken from the World Bank. Renewable energy production per capita comes from the Statistical Bureau of Korea. The unit labor cost is obtained from OECD data. Data sets from 1989 to 2016 are employed and a brief description of the variables is shown as follows.

In 1989, the volume of renewable energy production per capita was $51.2 \mathrm{~kg}$ of oil equivalent. It had increased slowly by $75.1 \mathrm{~kg}$ in 2000 and then shown a higher growth rate in the 2000s. In 2016 it recorded $292.2 \mathrm{~kg}$ of oil equivalent. In the same period, the number of registered patents also has increased. In 1989, it was 7,020, but it has increased more than 10 times by 2000 and turned out 163,424 in 2016. The unit labor cost also shows an increasing trend. In 1989, it was 52.7 and increased by 107.0 in 2007. Since that year, it has decreased for a few years and it has been recovered by the level of 2007. The share of industry in GDP has fluctuated in the period. Since 1991 when it reached the highest level $(40.2 \%)$, it has stayed at the level of late $30 \%$. 


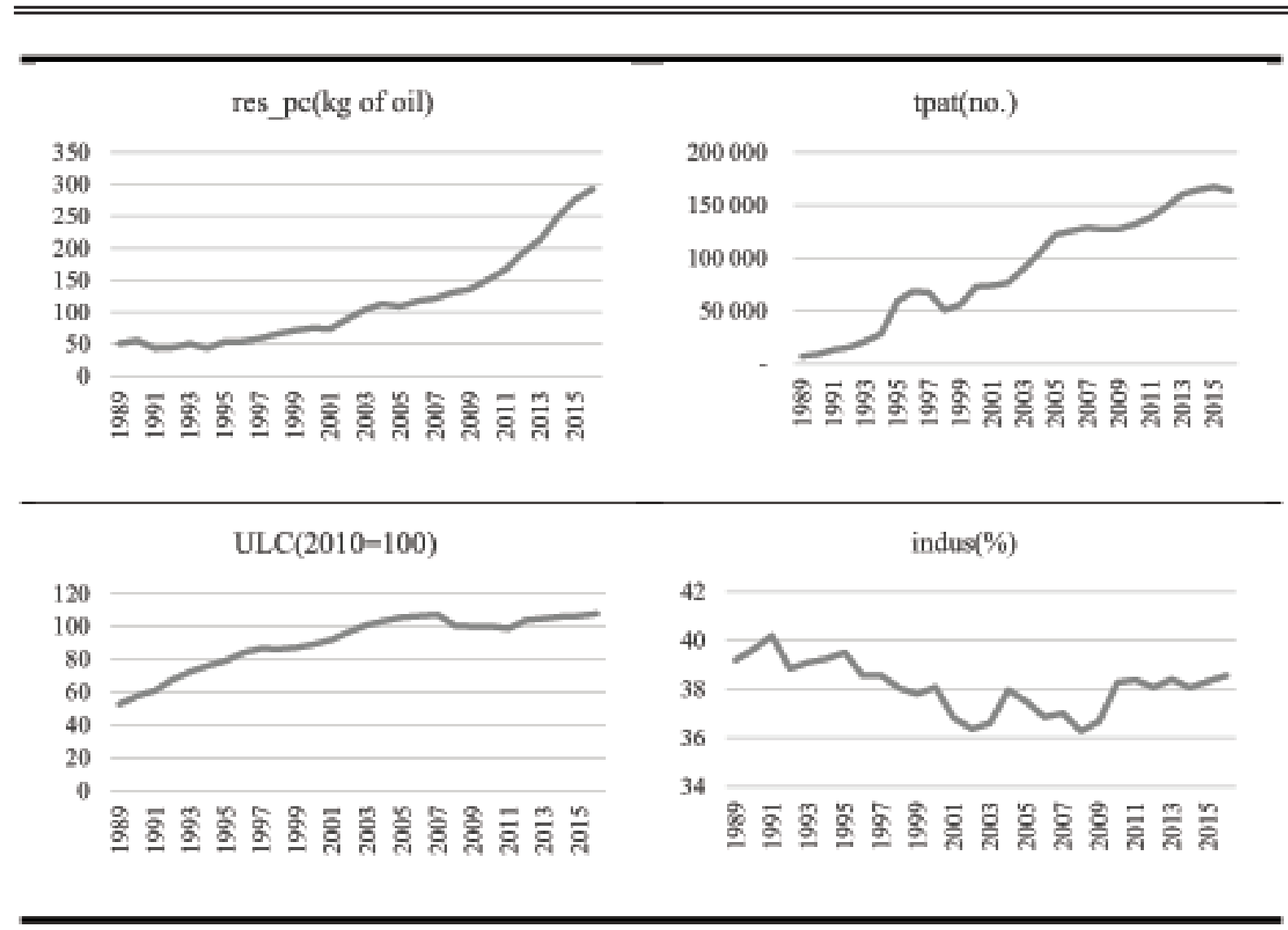

Figure 4. Renewable energy output per capita, total number of patents, unit labor costs, and share of the industrial sector in GDP

Source: World Bank ${ }^{3}, \mathrm{OECD}^{4}$

First, consider the long-term basic function for the RCA index for the renewable energy industry as follow.

$$
R C A_{-} a l l_{t}=\beta_{0}+\beta_{1} \text { lres_p }_{-} c_{t}+\beta_{2} \text { indus }_{t}+\beta_{3} \text { ltpat } t+\beta_{4} \text { lulc }_{t}+\epsilon_{t} \ldots \quad \text { [Eq. 3] }
$$

Where, $R C A$ all represents the weighted average sum of the RCA index of the renewable energy industry, lres $p c$, represents the renewable energy output per capita (log), lexcr represents the official exchange rate

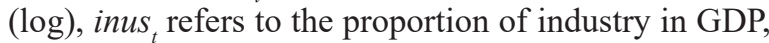
ltpat is the total amount of patents $(\log ), l u l c$ refers to unit labor $\operatorname{cost}(\log ), \in_{t}$ is an error term that includes all factors that affect energy demand except the explanatory variables. Taking into account the availability of the data required to calculate the RCA index, data from 1989 to 2016 were employed. The results of unit root tests on these variables are shown in (table 2).

Table 2. Result of the ADF unit root test

\begin{tabular}{c|c|c}
\hline Variable & Lag length & Korea \\
\hline$R C A \_a l l_{t}$ & 0 & -1.731137 \\
\hline lres_pc $c_{t}$ & 0 & -2.883063 \\
\hline$l t p a t_{t}$ & 6 & -1.399913 \\
\hline
\end{tabular}

World Bank. World Bank Open Data. Available at:https://data.worldbank.org/(accessed 10.12.2019) (in English).

OECD. OECD data. Available at: https://data.oecd.org/lprdty/unit-labour-costs.htm / (accessed 10.12.2019) (in english). 


\begin{tabular}{c|c|c}
\hline \hline Variable & Lag length & Korea \\
\hline lulc $c_{t}$ & 0 & -2.995109 \\
\hline indus $s_{t}$ & 0 & -1.641679 \\
\hline$\Delta R C A \_a l l_{t}$ & 0 & $-5.115832^{* * *}$ \\
\hline$\Delta$ lres_pc $c_{t}$ & 0 & $-5.777666^{* * *}$ \\
\hline$\Delta l t p a t_{t}$ & 2 & $-2.648132^{*}$ \\
\hline$\Delta l u l c_{t}$ & 0 & $-2.864355^{* *}$ \\
\hline Dindus & 0 & $-5.342540^{* * *}$ \\
\hline
\end{tabular}

Note: $* * *, * * *$ refers significance level at $1 \%, 5 \%, 10 \%$

As a result of the unit root test, it was con rmed that the unit root exists in all variables and it is an integrated type of time series following the I (1) process. In the model including both the RCA index and the four explanatory variables, there is an appropriate number of cointegration vectors. However, there is no statistically signi cant model in the cointegration regres- sion model including all four independent variables. The model with the explanatory variables $l r e s_{-} p c_{t}$ , ltpat ${ }_{t}, l u l c_{t}$ appears statistically signi cant. The result of the Johansen cointegration test, which is conducted with only lres_p $c_{t}$, ltpat ${ }_{t}$, lulc $c_{t}$, and the dependent variable $R C A_{-} a l l_{t}$ is shown in (table 3 ) below.

Table 3. Johansen Cointegration Test for RES RCA

\begin{tabular}{|c|c|c|c|c|c|}
\hline \multirow{2}{*}{ Country } & $\operatorname{Rank}(k)$ & $\lambda_{\text {trace }}$ & $5 \%$ Critical Value* & $\lambda_{\max }$ & $5 \%$ Critical Value \\
\hline \multirow{3}{*}{ Korea } & 0 & 64.67147 & 47.85613 & 35.45052 & 27.58434 \\
\cline { 2 - 6 } & 1 & 29.22094 & 29.79707 & 23.37794 & 21.13162 \\
\cline { 2 - 6 } & 2 & 5.843002 & 15.49471 & 5.724572 & 14.26460 \\
\cline { 2 - 6 } & 3 & 0.118429 & 3.841466 & 0.118429 & 3.841466 \\
\hline \\
Note: Lag 2 on AIC \\
* in the case of Japan, 10\% critical value is applied
\end{tabular}

As shown in the above table, in the Trace and Maximum Eigenvalue statistics, the variables have one and two cointegration vectors at the 5\% threshold, respectively. Thus, it is confirmed that the variables forming the cointegration regression model have I (1) process with a unit root and the cointegration vector exists between them. Let us now estimate the long-term export competitiveness function using the dynamic OLS estimator. The estimated regression equation for obtaining the DOLS estimator is as follows.

$$
\begin{aligned}
& R C A_{-} a l l_{t}=\beta_{0}+\beta_{1} \text { lres_p }_{-}+\beta_{2} \text { ltpat }_{t}+\beta_{3} \text { lulc } c_{t}+\sum_{j=-k}^{k} \theta_{1, j} \Delta l r e s_{-} p c_{t-j}+ \\
& \sum_{j=-k}^{k} \theta_{2, j} \Delta l t p a t_{t-j}+\sum_{j=-k}^{k} \theta_{3, j} \Delta l u l c_{t-j}+e_{t}
\end{aligned}
$$

Table 4 shows the results of the cointegration regression model for the RCA index of the renewable energy industries in Korea. The signs of coef cient consist with the theoretical expectation. The volume of renewable energy production per capita and the number of patent registrations are denoted by a coef cient of + and the unit labor cost is denoted by a coef cient of -, and all three explanatory variables are statistically signi cant at $1 \%$ level. R squared values were very high. 
Table 4. Result of the cointegration regression model for the RCA index

\begin{tabular}{|c|c|c|c|}
\hline Variable & Coefficient & Prob. & R-squared \\
\hline lres_p $c_{t}$ & $\begin{array}{c}0.903463 \\
(0.056966)\end{array}$ & 0.0001 & 0.999785 \\
\hline ltpat $t$ & $\begin{array}{c}2.932032 \\
(0.220896)\end{array}$ & 0.0002 & \\
\hline lulc $c_{t}$ & $\begin{array}{c}-11.95372 \\
(0.501520)\end{array}$ & 0.0000 & \\
\hline
\end{tabular}

Note: Figures in parentheses are Newey-West HAC standard error estimates. The order of the time lag and the lead of variable is set to 2 based on the SIC

The result indicates that the volume of renewable energy production has the smallest impact on the RCA index. As its coefficient indicates, the effect of economies of scale and scope of the RES production on the international competitiveness of RES related products of Korea is not only the smallest among the variable but also inelastic. It does not coincide with the results of some cross-section research on the subject and conventional expectation of the policymakers, which means the impact of the productivity by the economies of scale and scope,is not strong as much as expected. The impact of technological development turns out positive and elastic on the improvement of the international competitiveness of RES related products as the coefficient of the total number of the patent application has a bigger value than +1 . The RES related products have diverse products and devices as its sub-components by sources. For example, 17 kinds of products are included in the solar power products and they have diverse features from simple manufactured products, such as "glass mirror (HS-code: 700991 \& 700992)", to mechanic and electronic products, such as "Engines and motors (HS-code: 841280)" and "Photosensitive/ photovoltaic/LED semiconductor devices (HS-code: 854140)". Therefore, the overall improvement of the technological level in a country brings an increase in the international competitiveness of RES products that consist of diverse factors of the industries. The unit labor cost has the biggest impact on the composite RCA index. Its impact is almost 4 times bigger than the total patents applications. It quite well represents the RES related products as industrial outputs, which means in the global market RES related products of a country compete with others in not only the quality of the products but also quantity and price of the products. And labor productivity is one of the critical factors that may influence the quantity and price in Korea.

\section{Conclusion}

In this article, we assess the international competitiveness of RES related products in Korea by using the RCA index. Korea has a 1-point level index value in bioenergy products, hydro energy products, geothermal energy products, and ocean energy products, so it can be said that RES related products of Korea have relative comparative advantage in the global market. In the solar energy products, Korea has high competitiveness with late 3-point RCA index. In particular, the solar energy products lead tothe improvement of the RCA index showing a 9.3\% average annual growth rate. On the other hand, the RCA index of the wind energy products turns out 0.8 in 2016, so it is the only category that Korea has a comparative disadvantage. Although it has shown a 5.4\% average annual growth rate since 2000, but the index value is still under 1 . The composite RCA index of Korea shows relatively favorable competitiveness with a 2-point level for the last 10 years and a $6.5 \%$ average annual growth rate since 2000 . Based on these results, it can be said that RES related products of Korea have the competitiveness in the global market overall. However, the continuous comparative disadvantage in wind energy products, which is one of the fastest-growing markets, is remained as a task to solve for enhancing the international competitiveness of RES related products. Meanwhile, we analyze the determinants of the composite RCA index using cointegration regression. As a result, it turns out that the improvement of productivity and technological advancement give a positive impact on the international competitiveness of RES related products and the increase in efficiency by the expansion of domestic RES production also give a positive impact, but it is inelastic. In other words, the effect of the economies of scale and scope due to the increase in RES production is not high as much as expected. Therefore, in order to improve competitiveness, it is effective to take economic policies that help technological advancement and improvement of productivity such as investments and education than energy policy for increasing production of renewable energy.

The global market for RES related products, which has rapidly grown since 2000 , is considered a new market offering opportunity not only to developed countries, such as the USA and Germany, but also to developing countries like China. Korea is one of the most advanced industrialized countries, which has an export-oriented economic structure and merely no endowed energy resources. Therefore, expanding the use 
of renewable energy resources and the development of the related industries have been continuously stressed as one of the top-priority tasks of economic and security policy in the "National Energy Master Plan" 5 " and "National Renewable energy Master plan" of Korea.
On these conditions, the result of this article could give contributions to not only the policy-making of Korea, but also the following research on the assessing international competitiveness of RES related products in the individual country and analyzing the determinants.

\section{References}

1. Ellabban, O, Abu-Rub, H. and Blaabjerg, F. (2014) Renewable energy resources: Current status, future prospects and their enabling technology," Renew. Sustain. Energy Rev., vol. 39, pp. 748-764, Nov. 2014. Available at: www.sciencedirect.com/science/article/pii/S1364032114005656?via\%3Dihub (accessed 20.12.2019) (In Eng.).

2. Zhao, Z.-Y., Chen, Y.-L.(2018) Critical factors affecting the development of renewable energy power generation: Evidence from China, J. Clean. Prod., vol. 184, pp. 466-480, May 2018. Available at: http://www.sciencedirect.com.ssl.access.hanyang.ac.kr/science/article/pii/S0959652618305869 (accessed 20.12.2019) (In Eng.).

3. Boqiang, Lin, O.E., Omojub Jennifer, Okonkwoc, U. (2016) Factors influencing renewable electricity consumption in China. Renew. Sustain. Energy Rev., Vol. 55, pp. 687-696, Mar. 2016. Available at: www.sciencedirect.com.access.hanyang.ac.kr/science/article/pii/S1364032115012538 (accessed 20.12.2019) (In Eng.).

4. Jing, S., Fubin, H., Zhihui, L., Xin, C. (2019) International competitiveness of China's biomass products: a CMS and RCA analysis. Int. J. Energy Sect. Manag., Vol. ahead-of-p, no. ahead-of-print, Jan. 2019. Available at: https://doi.org/10.1108/IJESM-05-2019-0013 (accessed 20.12.2019) (In Eng.).

5. Papież, M., Śmiech, S., Frodyma, K. (2018) Determinants of renewable energy development in the EU countries. A 20-year perspective. Renew. Sustain. Energy Rev. Vol. 91, pp. 918-934, Available at: www.sciencedirect.com/science/article/pii/S1364032118303034 (accessed 20.12.2019) (In Eng.).

6. Kuik, O., Branger, F., Quirion, P. (2019) Competitive advantage in the renewable energy industry: Evidence from a gravity model. Renew. Energy, Vol. 131, pp. 472-481. Available at: www.sciencedirect.com/science/ article/pii/S0960148118308437 (accessed 20.12.2019) (In Eng.).

7. Marques, A.C., Fuinhas, J.A., Manso, J.P. (2011) A Quantile Approach to Identify Factors Promoting Renewable Energy in European Countries. Environ. Resour. Econ. Vol. 49, no. 3, pp. 351-366. Available at: https:// doi.org/10.1007/s10640-010-9436-8 (accessed 20.12.2019) (In Eng.).

8. Przychodzen, W., Przychodzen, J. (2020) Determinants of renewable energy production in transition economies: A panel data approach," Energy. Vol. 191, p. 116583. Available at: https://www.sciencedirect.com/ science /article/pii/S0360544219322789 (accessed 20.12.2019) (In Eng.).

9. Yoo, Jin-Man (2015) International Competitiveness in the New Renewable Energy Industry : An Empirical Study. Korea trade Rev. Vol. 40, no. 3, pp. 91-118. Availble at: http://www.dbpia.co.kr.access.hanyang.ac.kr / Journal/ArticleDetail/NODE06380682 (accessed 20.12.2019) (In Korean).

10. Kim, D. (2017) An empirical study of policy instruments for renewable energy growth - Focusing on the interaction between policy instruments and government effectiveness. Korean Public Adm. Rev. Vol. 51, no. 2, pp. 33-59. Available at: http://www.dbpia.co.kr.access.hanyang.ac.kr/ Journal/ArticleDetail/NODE07192556 (accessed 20.12.2019) (In Korean).

11. Kim, T. (2011) Determinants of New Renewable Energy Growth: Empirical Testing of the Effectiveness of Feed-In Tariff and Renewable Portfolio Standard Policy). Korean Public Adm. Rev. Vol. 45, no. 3, pp. 305333. Available at: http://www.dbpia.co.kr.access.hanyang.ac.kr/Journal/ArticleDetail/ NODE06715099 (accessed 20.12.2019) (In Korean).

12. Fang, K., Guo, S., Zhou, Y., Wang, S.R.Ye (2018) Renewable Energy Competitiveness Of The G20 Nations. Sci. Trends. Available at: www.sciencedirect.com/science/article/pii/S136403211830354X?via\%3Dihub (accessed 20.12.2019) (In Eng.).

13. Jha, V. (2009) Trade flows, barriers and market drivers in renewable energy supply goods: The need to level the playing field. Available at: https://www.jstor.org/stable/40440305?seq=1 (accessed 20.12.2019) (In Eng.)

14. Fagerberg, J. (1988) International Competitiveness. Econ. J., vol. 98, no. 391, pp. 355-374. Available at: https://www.jstor.org/stable/2233372 (accessed 20.12.2019) (In Eng. ).

15. BOLTHO, A. (196) THE ASSESSMENT: INTERNATIONAL COMPETITIVENESS. Oxford Rev. Econ.

Ministry of Trade, Industry and Energy of Korea, “3rd National Energy Master Plan”, 2019 (http://www.motie.go.kr/common/download. do?fid=bbs\&bbs_cd_n=42\&bbs_seq_n=219\&file_seq_n=1) (accessed 20.12.2019) (in Korean).

Ministry of Trade, Industry and Energy of Korea, “4th National Renewable energy Master Plan”. 2014 (https://www.index.go.kr/com/ $\mathrm{cmm} / \mathrm{fms} /$ FileDown.do?apnd_file_id=1171\&apnd_file_seq=6) (accessed 20.12.2019) (in Korean). 
Policy, Vol. 12, no. 3, pp. 1-16, Available at: http://www.jstor.org/stable/23606437 (accessed 20.12.2019) (In Eng.).

16. Antoine Magnier, Toujas-Bernate, J. (1994) Technology and Trade: Empirical Evidence for the Major Five Industrialized Countries. Weltwirtsch. Arch., Vol. 130, pp. 494-520. Available at: https://www.jstor.org/stable/40440305 (accessed 20.12.2019) (In Eng.).

17. Carlin, A. G., Reene, J. (2001) Export Market Performance of OECD Countries: An Empirical Examination of the Role of Cost Competitiveness. Econ. J., Vol. 111, no. Jan, pp. 128-162. Available at: https://onlinelibrary.wiley.com/doi/abs/10.1111/1468-0297.00592 (accessed 20.12.2019) (In Eng.).

18. Amable, B., Verspagen, B. (1995) The Role of Technology in Market Shares Dynamics. Appl. Econ., Vol. 27, pp. 197-204. Available at: https://www.tandfonline.com/doi/abs/10.1080/00036849500000024 (accessed 20.12.2019) (In Eng.).

19. P. T. and R. W. Greenhalgh (1984) Innovation and Export Volumes and Prices: A Disaggregated Studyю Oxf. Econ. Pap., Vol. 46, pp. 102-134. Available at: https://www.jstor.org/stable/2663526 (accessed 20.12.2019) (in English).

20. R. M. and L. S. Hulst, (1991) Export and Technology in Manufacturing Industry. Weltwirtsch. Arch., pp. 247-264. Available at: https://link.springer.com/article/10.1007/BF02707985 (accessed 20.12.2019) (In Eng.).

21. Engle, R.F., Granger, C.W.J. (1987) Co-Integration and Error Correction: Representation, Estimation, and Testing. Econometrica. Vol. 55, no. 2, pp. 251-276. Available at: http:/www.jstor.org/stable/1913236 (accessed 20.12.2019) (In Eng.).

22. Johansen, S. (1991) Estimation and Hypothesis Testing of Cointegration Vectors in Gaussian Vector Autoregressive Models. Econometrica, Vol. 59, no. 6, pp. 1551-1580. Available at: http://www.jstor.org/stable/2938278 (accessed 20.12.2019) (In Eng.).

23. Youngsoo, Bae (2015) Estimation and Forecast of Long-run Energy Demand Function : A Cointegration Approach. Korean Energy Econ. Rev. Vol. 14, no. 2, pp. 21-50. Available at: http://www.dbpia.co.kr/Article/ NODE06525971 (accessed 20.12.2019) (In Korean).

Information about the author:

Yoon, Youngmin, Attached Faculty of Economics, Lomonosov Moscow State University, Moscow, Russia / Participating researcher in Asia-Pacific Research center, Hanyang University, Seoul, Republic of Korea e-mail: yoonym81@gmail.com

The paper was submitted: 06.03.2020.

Accepted for publication: 28.04.2020.

The author has read and approved the final manuscript.

Информация об авторе:

Ён Юнг Мин, соискатель экономического факультета, Московский государственный университет имени М. В. Ломоносова, Москва, Россия / научный сотрудник, Азиатско-Тихоокеанский исследовательский центр, Ханьянский университет, Сеул, Республика Корея

e-mail: yoonym81@gmail.com

Статья поступила в редакцию: 06.03.2020; принята в печать: 28.04.2020.

Автор прочитал и одобрил окончательный вариант рукописи. 